\title{
Atmospheric Corrosion of Reinforced Concrete Steel in Tropical Coastal Regions
}

\author{
Abel Castañeda ${ }^{1} *$, Francisco Corvo ${ }^{2}$, Juan José Howland ${ }^{3}$, and Tezozomoc Pérez ${ }^{2}$ \\ 1 National Center for Scientific Research, P.O. Box 6412, Havana City, Cuba \\ 2 Corrosion Research Center, University of Campeche, P.O. Box 24030, Campeche, Mexico \\ 3 Polytechnic Institute, Civil Engineering School, P.O. Box 19390, Havana City, Cuba \\ * E-mail: abel.castaneda@cnic.edu.cu (Corresponding author)
}

\begin{abstract}
The influence of atmospheric parameters and chloride deposition rate on concrete using an atmospheric corrosion approach is rarely found in literature. Seven exposure sites were selected in Havana, Cuba and two at Yucatan Peninsula, Mexico, to expose reinforced concrete samples. Two significantly different atmospheric corrosivity levels have been observed after two years of exposure in Havana depending on atmospheric chloride deposition and the $\mathrm{w} / \mathrm{c}$ ratio of the concretes. Changes in corrosion current are in accordance with changes in chloride concentrations into concrete and chloride deposition rate. The influence of sulphur compounds deposition rate should be considered to study atmospheric corrosion of reinforced concretes in Havana.
\end{abstract}

Keywords: Concrete, reinforced concrete, atmospheric corrosion, chlorides, water/cement ratio.

ENGINEERING JOURNAL Volume 17 Issue 2

Received 21 August 2012

Accepted 14 October 2012

Published 1 April 2013

Online at http://www.engj.org/

DOI:10.4186/ ej.2013.17.2.1 


\section{Introduction}

Atmospheric corrosivity for metals ranges from C3 to >C5 is according to ISO 9223 standard in tropical coastal atmospheres [1-2]. The influence of atmospheric parameters, chloride deposition rate and other contaminants on metals in tropical climate have been extensively studied; however, in the case of reinforced concrete structure, chloride deposition rate is not directly related to corrosion of the reinforcing steel rebars because the chloride penetration rate into the concrete cover to reach the reinforcing steel rebars surface depends on the concrete properties, particularly it capillarity and porosity [3-10]. The development of the pore structure of hydrating Portland cement systems is fundamental to behavior of concrete exposed to a variety of aggressive environments. It influences mass transport of ions into the material and their interaction with concrete constituents as well as the diffusion characteristics of concrete [11]. Gradients of moisture content, hydrostatic pressure, stress, temperature, concentration of aggressive chemicals, and the diameter and distribution of permeable pores in the concrete, disturb the equilibrium state of fluids in a porous material, therefore, the transfer of fluid flux occurs in order to restore the equilibrium. This process of transport of fluid flux is generally described in terms of adsorption, diffusion, absorption, and permeability. The state of water in the concrete pore influences on these processes.

Atmospheric corrosion aggressivity for metals is established based in weight loss or environmental parameters [1]. Respecting to reinforcing steel rebars, localized corrosion (usually called as pitting corrosion) is the predominant type. That is not the case for metals in the atmosphere, where generalized corrosion is very frequent, excepting passive metals like aluminum and others. Under this approach, an evaluation of atmospheric corrosivity respecting reinforcing steel rebars should be different. In the case of coatings, the necessary time for visual deterioration is an important factor; for example, time for changes in color, presence of corrosion products in the concrete surface, presence of blisters and other defects are very important. From the corrosion point of view, concrete cover can be considered as a protective composite coating deposited on reinforcing steel rebars. This protective coating is characterized for a relative thickness and high porosity. In the case of paint and varnishes, recommendations are made to use paints as protective coatings depending on the corrosivity of the environment [12]. In the case of paints and concrete, corrosivity should be defined based on durability time and not on metal loss. Concrete cover properties changes in a relatively wide range and they are very important for determining chloride concentration, that is why it is a difficult task to establish a relative prediction of reinforced concrete durability in coastal and marine zones based on atmospheric salinity deposition. The same situation occurs for metals and coatings, because there is a wide range of coatings and metal alloys. Under such circumstances, standard reference samples could be used as patterns for atmospheric corrosivity, in the same way as occurs on metals.

Significant corrosion of reinforcing steel rebars in the reinforced concrete structure starts when chloride threshold is reached and after this moment the corrosion damage of the structure increases very fast [13]. Under this conception, the most important parameter to be determined respecting the influence of the environment in coastal and marine sites is the necessary time to reach the critical chloride content or chloride threshold in the reinforcing steel rebars surface. This time does not depend only on the chloride deposition rate and other atmospheric parameters, but also on the properties of concrete, particularly capillarity, cover thickness of steel rebars and so on. It is the time in which corrosion initiates. After this time, corrosion propagates and its rate is relatively fast, depending on the environment and the properties of concrete cover. Corrosion current could be an index about the influence of chloride content in reinforcing steel bars corrosion but it should be applied considering the type of corrosion, because when generalized corrosion occurs, corrosion attack takes place in almost all the metallic surface, but when localized corrosion occurs there are areas of the metallic surface where corrosion attack is localized while other areas remain without significant corrosion.

Bastidas-Arteaga et al. described the influence of the distance from the sea on the probability of corrosion initiation using a stochastic model [14].The impact of the distance to the sea was observed by analyzing the results for a lifespan of 30 years. It was noted that for all locations, the probability of corrosion initiation is higher for the tropical environment. Tropical environments are characterized by higher values of temperature and humidity, it causes that the time to corrosion initiation is reduced. The influence of the distance to the seashore in Yucatan Peninsula on reinforcing steel rebars corrosion was extensively studied by Castro [15].

To study the influence of atmospheric environment on different types of concrete was the main objective of the CYTED project DURACON, developed between 11 Iberoamerican countries [16]. The 
first results obtained showed that in marine atmospheres, chloride deposition rate should be considered a decisive factor when evaluating the probability of reinforcing steel rebars corrosion [17].

Deposition measurements are a common way to analyze salt presence in the atmosphere. The wet candle device is frequently used for this purpose, as part of standardized procedures to measure the amount of chloride salts which is captured from the atmosphere on a prescribed exposed area of the apparatus. A decreasing tendency for the total amount of chlorides that penetrate into reinforced concrete structures built in coastal atmospheres as function of distance to the shoreline have been observed under natural exposures [18].

Chlorides present in the atmosphere, which represent the availability to deposit on the reinforced concrete surface and penetrate into concrete, can be studied using different methods, including the wet candle and the dry plate methods. The results can be correlated with chlorides accumulated into concrete. Recently, chloride penetration in different types of mortars is reported for a tropical country (Bangla Desh) [19]. A relative small chloride deposition rate is determined using the wet candle method in the coastal zone, where maxima oscillated around $60 \mathrm{mg} / \mathrm{m}^{2} \mathrm{~d}$; however for Brazil, Meira proposed that chloride deposition rate on the wet candle can be used as an environmental indicator, helping to preview the expectancy of service life of concrete structures or suggesting minimum concrete steel rebars cover thicknesses for a required service life [20]. It is concluded that service life can vary between $30 \%$ and $60 \%$ if the same concrete is in a marine atmosphere zone with $120 \mathrm{mg} / \mathrm{m}^{2} \mathrm{~d}$ or with $500 \mathrm{mg} / \mathrm{m}^{2} \mathrm{~d}$, which represents an increase of more than four times on chloride deposition rate.

The main objective of the present paper is to obtain valuable information for maintenance, construction, designing and protection of reinforced concrete structures in the coastal regions in Havana City and Yucatan Peninsula. A significant damage of reinforced concrete structures has been observed near the Havana City.

\section{Experimental Procedure}

Two sets of experiments have been performed. Seven exposure sites were selected in Havana City Cuba, at different distances to the north seashore. Cuba is a long and Narrow Island located almost parallel to the Equator. Havana city is located in the north seashore in the west side of the Island. In the present paper, results of two years of exposure are reported.

The other experiment was carried out in the Yucatan Peninsula, Mexico. Two exposure sites were selected close to the Mexican Gulf shoreline. Yucatan Peninsula is placed also in tropical climate. Average temperature in the exposure sites is slightly higher than in Cuba and relative humidity is slightly lower. This experiment was performed only during one year of exposure and is reported for comparison [2].

Concrete samples were prepared using aggregates of the surrounding region. It causes that concrete samples properties for Havana and Yucatan are significantly different. It is useful to compare their behavior in tropical coastal atmospheres.

\section{Exposure sites in Havana City Cuba}

Seven exposure sites selected at Havana City Cuba to different distances to the shoreline were showed (Fig. 1). According to the location of the sites, an extreme atmospheric corrosivity ( $>$ C5) should be expected at site No.1 because it is located at less than $20 \mathrm{~m}$ of the Cuban north shoreline, followed by site No. 2 and the site No. 3 in a lower level of corrosivity [3]. The influence of airborne salinity should be lower at sites located at a distance higher than $1 \mathrm{~km}$ to the shoreline, excepting site No.4 (there is a previous report of atmospheric corrosivity level for this site-C4) site which is located close to Havana Bay [2].

Temperature and relative humidity, on the seven sites, were measured (using data loggers) every 0.5 hours during the first year. The measuring period was September 2007-August 2008 (Table 1). It can be observed that average temperature oscillates between 26.1 and $28.6^{\circ} \mathrm{C}$. Although changes in temperature are small, an increase in average temperature is observed when distance to the shoreline increases. These conditions should slightly enhanced chloride penetration in samples near the shoreline because condensation of moisture is favored at lower temperature. 

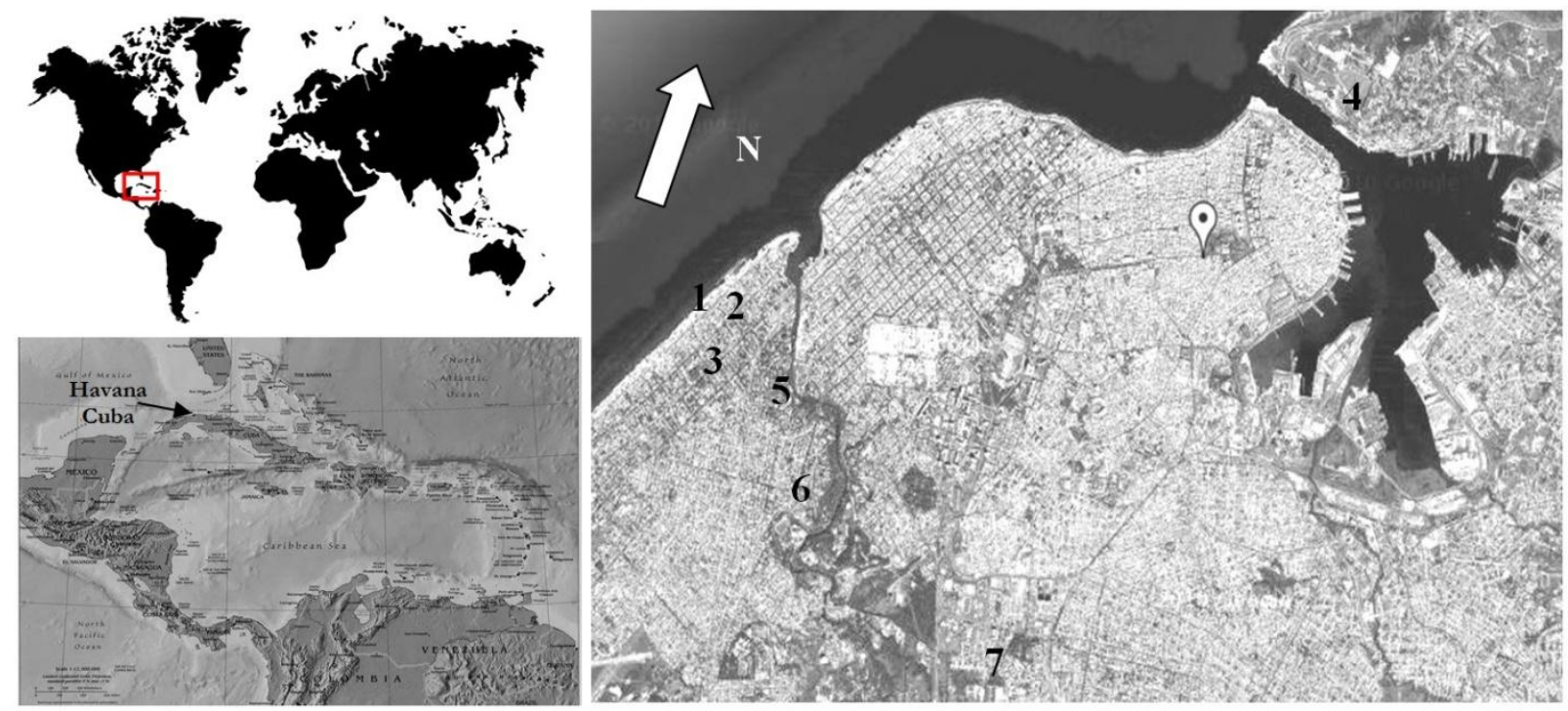

Fig. 1. Seven exposure sites selected at Havana City Cuba at different distances to the shoreline.

Respecting relative humidity, average values are lower for the two sites located far from the shoreline, corresponding to the higher average temperature. Sites located closer to the shoreline show relative humidity average over $80 \%$ (Table 1). These conditions show that the chlorides concentrations should be enhanced on sites close to the shoreline because porous system should be more saturated by water. At the same time, chloride deposition rate is higher near the shoreline.

\section{Exposure sites in Yucatan Peninsula Mexico}

The two exposure sites selected at Yucatan Peninsula were showed (Fig. 2). The site No. 8, located at Yucatan State, very close to the shoreline, and the site No. 9, located at Campeche State and also close to the shoreline, but under conditions of lower airborne salinity due to the wind pattern distribution [1].
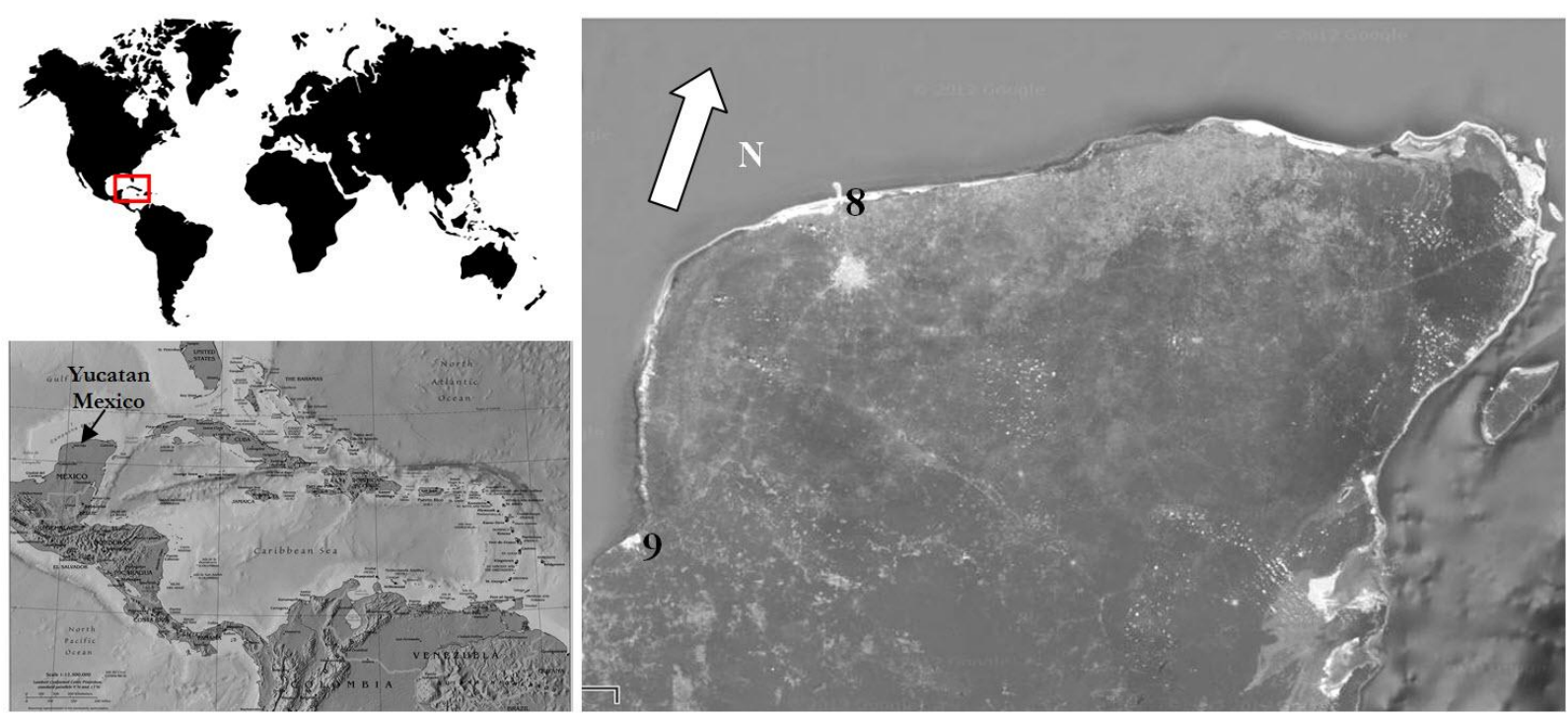

Fig. 2. Two exposure sites selected at Yucatan Peninsula Mexico to different distances to the shoreline.

Information about corrosivity according to ISO 9223 classification for all exposure sites is presented (Table 1) from the time of wetness in function of chloride and sulphur compounds deposition rate. In the case of the sites No. 4, 8 and 9, atmospheric corrosivity has been classified in previous investigations [2]. The classification of corrosivity for the other exposure sites has been made based on levels established on ISO 9223 according to environmental parameters [1]. 
Table 1. Climate parameters, average deposition rate, and estimated corrosivity classification according to ISO 9223 for Cuban and Mexican sites located to different distances to the shoreline.

\begin{tabular}{|c|c|c|c|c|c|c|c|c|c|}
\hline \multirow{2}{*}{$\begin{array}{l}\text { Country } \\
\text { Exposure site } \\
\text { Distance to shoreline (m) }\end{array}$} & \multicolumn{7}{|c|}{ Cuba } & \multicolumn{2}{|c|}{ Mexico } \\
\hline & $\begin{array}{c}1 \\
(20)\end{array}$ & $\begin{array}{c}2 \\
(360)\end{array}$ & $\begin{array}{c}3 \\
(615)\end{array}$ & $\begin{array}{c}4 \\
(1500)\end{array}$ & $\begin{array}{c}5 \\
(1600)\end{array}$ & $\begin{array}{c}6 \\
(2678)\end{array}$ & $\begin{array}{c}7 \\
(4500)\end{array}$ & $\begin{array}{c}8 \\
(50)\end{array}$ & $\begin{array}{c}9 \\
(150)\end{array}$ \\
\hline & \multicolumn{9}{|c|}{ Yearly Average } \\
\hline $\begin{array}{l}\text { Relative Humidity } \\
(\%)\end{array}$ & 81.0 & 81.6 & 83.8 & 82.5 & 83.2 & 77.1 & 77.2 & - & - \\
\hline $\begin{array}{l}\text { Temperature } \\
\left({ }^{\circ} \mathrm{C}\right)\end{array}$ & 26.1 & 26.2 & 26.6 & 28.1 & 26.5 & 28.6 & 27.9 & - & - \\
\hline $\begin{array}{l}\text { Time of wetness } \\
(\mathrm{h} / \mathrm{y})\end{array}$ & 4966 & 4789 & 4489 & 3495 & 4576 & 3782 & 3224 & 2826 & - \\
\hline $\begin{array}{l}\text { Chloride deposition rate } \\
\left(\mathrm{mg} \mathrm{m}^{-2} \mathrm{~d}^{-1}\right)\end{array}$ & 719.5 & 16.3 & 4.2 & 13.0 & 2.9 & 2.7 & 1.9 & 470.8 & 70.5 \\
\hline $\begin{array}{l}\text { Sulphate deposition } \\
\text { rate }\left(\mathrm{mg} \mathrm{m}^{-2} \mathrm{~d}^{-1}\right)\end{array}$ & 57.7 & 21.6 & 20.5 & 28.5 & 18.0 & 15.1 & 18.2 & 2.6 & - \\
\hline $\begin{array}{l}\text { Corrosivity classification } \\
\text { according to ISO } 9223\end{array}$ & C5 & C3 & C3 & C3* & C3 & C3 & C3 & C5* & C3* \\
\hline
\end{tabular}

\section{Atmospheric corrosivity classification of corrosion sites}

It is important to note that site No. 2, a site located at $360 \mathrm{~m}$ of the shoreline, should report a significant chloride deposition rate [CIDR], but the direct arrival of airborne salinity to this site is difficult because samples are located in the back of a $12^{\text {th }}$ floor building placed in front to the shoreline (Table 1). A corrosivity level lower than expected according to the distance to the shoreline should be obtained.

Sites 2, 3 and 4 are closer to the shoreline, or the Havana Bay seashore. In addition, classification of chloride deposition rate is S1, higher than the other sites excepting Station No.1.

Sites 5, 6 and 7 are relatively far from the shoreline, under urban influence, and should have a lower atmospheric corrosivity (supposing not significant the influence of urban environment). Under these conditions, instead to a similar prediction of corrosivity using ISO 9223, differences in corrosivity should exists between sites located at a salinity classification S3 (20 m distance to the shoreline), other sites at a distance lower than $1 \mathrm{~km}$ to the shoreline (including site No. 4) with a S1 classification and those sites placed at more than $1 \mathrm{~km}$ to the shoreline (Stations 5,6 and 7) presenting So classification.

Exposure sites at Yucatan Peninsula Mexico show two significantly different atmospheric corrosivity levels because site No. 8 is a coastal site with significant chloride deposition rate is S3, and site No. 9, although it is a coastal site, due to the existing wind pattern, does not report high values of chloride deposition (S2).

\section{Concrete samples exposed in Havana City Cuba}

Nine concrete samples and six of reinforced concrete were prepared for every exposure site at Havana City Cuba. Dimension of the samples is $20 \mathrm{~cm} \times 20 \mathrm{~cm}$ x $20 \mathrm{~cm}$. Three water/cement (w/c) ratios were used: $0.4,0.5$ and 0.6. Three concrete samples two of reinforced concrete were used for each w/c ratio. Results obtained in the first and second year of exposure are presented in the present paper.

Four reinforcing steel rebars of $200 \mathrm{~mm}$ length, were placed in to every reinforced concrete sample, two reinforcing steel rebars at $20 \mathrm{~mm}$ cover and two corresponding to $40 \mathrm{~mm}$ cover. The distance between reinforcing steel rebars is $10 \mathrm{~mm}$ (Fig. 3). Previous introduction of the reinforcing steel rebars in concrete, chemical cleaning was carried out, in order to avoid any possible corrosion product in the surface and keep the surface in similar conditions. 


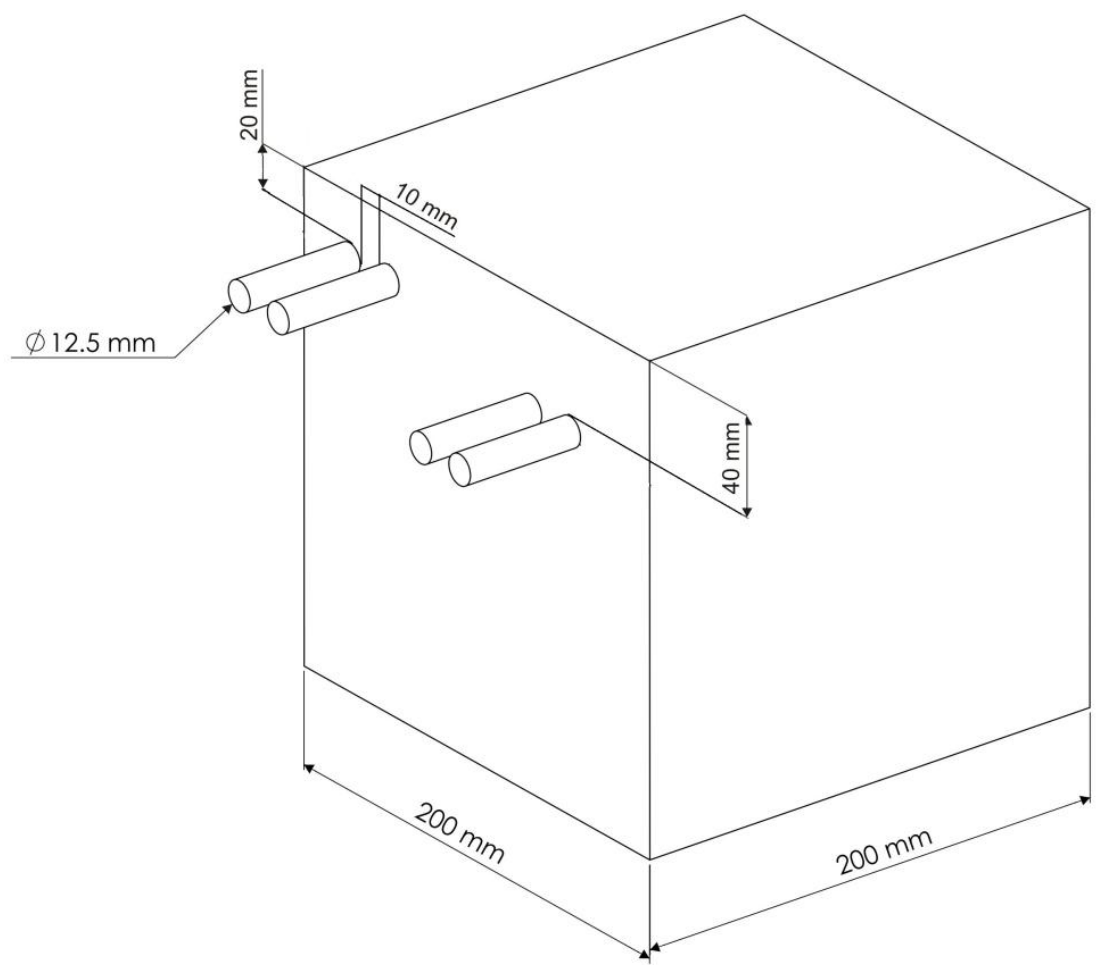

Fig. 3. Dimensions of concrete samples (including reinforcing steel rebars) prepared for exposure in exposure sites of Havana City.

Aggregates combination depending on $\mathrm{w} / \mathrm{c}$ ratio of the concretes is presented (Table 2). The origin of the different aggregates was the following: Portland cement P-350 produced at Cuban factory, washed sand original of quarry, gravel grade A (limestone), $19 \mathrm{~mm}$ of quarry too and superplasticizer admixture to reduces water content in the concretes about $20-25 \%$. The concrete consistency measured by the Abrams cone, the necessary water quantity and the admixture volume in the preparation of the concrete samples, according to w/c ratio are presented (Table 3). Slump was determined using the Abrams cone method [NC ISO 1920-2 Testing of concrete. Part 2: Properties of fresh concrete]. All samples were cured during 28 days by total immersion in water (curing tank).

Compressive strength was determined using a $2000 \mathrm{kN}$ testing machine. Concrete samples prepared for this test were of cylindrical shape (height $=30 \mathrm{~cm}$ and diameter $=15 \mathrm{~cm}$ ) and cured for 28 days by total immersion in water. Three values of concrete compressive strength were determined for each w/c ratio. The average compressive strength values in both countries were similar to mixed concrete manufactured in Indonesia, Japan and USA companies as reported [21].

Ultrasonic pulse velocity can be used as criteria of concrete homogeneity. A TIC PROCEQ model instrument was used to measure the ultrasonic pulse velocity. Transmission and detector were placed in parallel, obtaining a direct measure of ultrasonic pulse velocity. Two samples for every w/c ratio were evaluated. Evaluation was carried out in all parallel faces, three for every sample. In general, the average values obtained show that concrete homogeneity is acceptable (Table 3).

Capillarity absorption coefficient and effective porosity were determined based on the methodology established by Göran Fagerlund and according to Cuban standard [22]. Two cylindrical shape samples measuring $6.2 \mathrm{~cm}$ diameter were extracted in samples of $\mathrm{w} / \mathrm{c}$ ratio $0.4,0.5$ and 0.6 . These specimens were cut at $20 \mathrm{~mm}$ thickness. Every cylinder was cut into eight pieces. For every w/c ratio, 16 small cylinders measuring $20 \mathrm{~mm}$ height were obtained. All pieces were dried at $50{ }^{\circ} \mathrm{C}$ during $48 \mathrm{~h}$ into an oven up to constant weight. Samples were covered with paraffin wax on their sides. Afterwards, the pieces were placed in desiccators under low relative humidity.

Testing cylinders were placed on a layer of silica sand of about $10 \mathrm{~mm}$ thickness where water level was maintained $5 \mathrm{~mm}$ over the lower surface of the cylinders. Suction processes took place only by the lower surface. Every testing cylinder was weighted before placing on the sand layer and afterwards, at different times, according to the testing program, it was weighted again. An analytical balance ( $0.2 \mathrm{mg}$ accuracy) was used. 
Table 2. Concrete composition used in Havana and Yucatan site.

\begin{tabular}{|c|c|c|c|c|c|c|}
\hline \multirow{3}{*}{ Constituents } & \multicolumn{6}{|c|}{ Concrete water/cement ratio } \\
\hline & \multicolumn{2}{|c|}{0.4} & \multicolumn{2}{|c|}{0.5} & \multicolumn{2}{|c|}{0.6} \\
\hline & Yucatan & Havana & Yucatan & Havana & Yucatan & Havana \\
\hline $\begin{array}{l}\text { Cement } \\
(\mathrm{Kg})\end{array}$ & - & 365 & 400 & 365 & 350 & 365 \\
\hline $\begin{array}{l}\text { Sand } \\
(\mathrm{Kg})\end{array}$ & - & 750 & 888 & 750 & 888 & 750 \\
\hline $\begin{array}{l}\text { Coarse Aggregate } \\
(\mathrm{Kg})\end{array}$ & - & 1030 & 806 & 1030 & 881 & 1030 \\
\hline $\begin{array}{l}\text { Water } \\
\text { (L) }\end{array}$ & - & 148 & 200 & 186 & 203 & 222 \\
\hline $\begin{array}{l}\text { Water-reducing Admixture } \\
\text { (\% of cement weight) }\end{array}$ & - & 1.7 & - & 1.2 & - & 1.0 \\
\hline
\end{tabular}

Table 3. Abram's cone slump, compressive strength, density, capillarity absorption coefficient, effective porosity and ultrasound pulse velocity of the concrete samples prepared in Cuba and Mexico.

\begin{tabular}{|c|c|c|c|c|c|}
\hline \multirow{3}{*}{$\begin{array}{l}\text { Country } \\
\text { Concrete properties }\end{array}$} & \multicolumn{3}{|c|}{ Cuba } & \multicolumn{2}{|c|}{ Mexico } \\
\hline & \multicolumn{3}{|c|}{ Water/cement ratio } & \multicolumn{2}{|c|}{ Water/cement ratio } \\
\hline & 0.4 & 0.5 & 0.6 & 0.5 & 0.6 \\
\hline Slump $(\mathrm{cm})$ & 15 & 17 & 18 & 2 & 6 \\
\hline Compression strength $(\mathrm{MPa})$ & 35.1 & 29.4 & 25.6 & 25.7 & 19.1 \\
\hline Density $\left(\mathrm{kg} \mathrm{m}^{-3}\right)$ & 2352 & 2342 & 2308 & - & - \\
\hline Absorption capillary $\mathrm{K}\left(\mathrm{kg} \mathrm{m}^{-2} \mathrm{~s}^{-1 / 2}\right)$ & 0.00189 & 0.00559 & 0.0126 & - & - \\
\hline Porosity (\%) & 8.05 & 13.32 & 19.65 & - & - \\
\hline Ultrasound $\left(\mathrm{m} \mathrm{s}^{-1}\right)$ & 4241.6 & 4082.1 & 3920.8 & & \\
\hline
\end{tabular}

\section{Samples exposed at Yucatan sites}

This experiment was carried out previously to the one performed in Havana City Cuba. Although samples were not prepared in the same manner as in Havana, we consider important to analyze the differences in order to obtain more general conclusions.

Cylindrical specimens of $75 \mathrm{~mm}$ diameter x $150 \mathrm{~mm}$ length were prepared using Portland cement with a w/c ratio of 0.5 and 0.6. One batch of samples prepared using crushing calcareous aggregates, but only w/c ratio 0.5, was exposed at Station No.8 from August 1993 to August 1994. Samples of w/c ratio 0.5 and 0.6 were exposed at Station No.9 during February 1995 to January 1996. Natural river rounded gravels was used as aggregates. River aggregates present a lower contact area because their surface is less roughness.

The two extremes of the cylindrical specimens were covered with a bituminous coating to induce only a radial penetration.

Aggregates combination used is presented (Table 2). No plasticizer admixture was used. Samples were cured during 28 days. It is important to note that compressive resistance of samples prepared in Havana is significantly higher than those prepared at Yucatan. At the same time, slump (by the Abrams cone) is significantly lower for Yucatan samples. Although capillarity absorption coefficient and effective porosity were not measured, a higher capillarity and porosity should correspond to these samples respecting those prepared in Havana (Table 3). A higher chloride penetration should be expected.

\section{Measurement of pollution}

Chloride deposition rate [CIDR] was obtained using the dry plate device, consisting in the use of a piece of dry cotton fabric of dimension $320 \mathrm{~mm} \times 220 \mathrm{~mm}$ and kept stretched and perpendicular to the wind in a wood holder exposed under a shed (Fig. 4). The piece of dry cotton is changed at the end of each month in every exposure site and stored in polymer bag (September 2007 to August 2008). The amount of chloride deposition on the dry cotton is determined analytically by potentiometric titration with AgNO3 solution $0.05 \mathrm{M}$ and the deposition rate is calculated. Two values monthly, one to each dry plate device for a total of 24 values were obtained [23]. 
Sulfur compounds deposition rate $[\mathrm{SO} \times \mathrm{DR}]$ was obtained using alkaline plates of dimension $150 \mathrm{~mm} \times$ $100 \mathrm{~mm}$ and perpendicular to the wind too (Fig. 4). The piece is changed and stored like de dry cotton. The amount of sulphur compounds is determined by incineration of alkaline plates in a furnace at $750{ }^{\circ} \mathrm{C}$ temperature [24]. Two values monthly, one to each alkaline plate were obtained for a total of 24 values too.

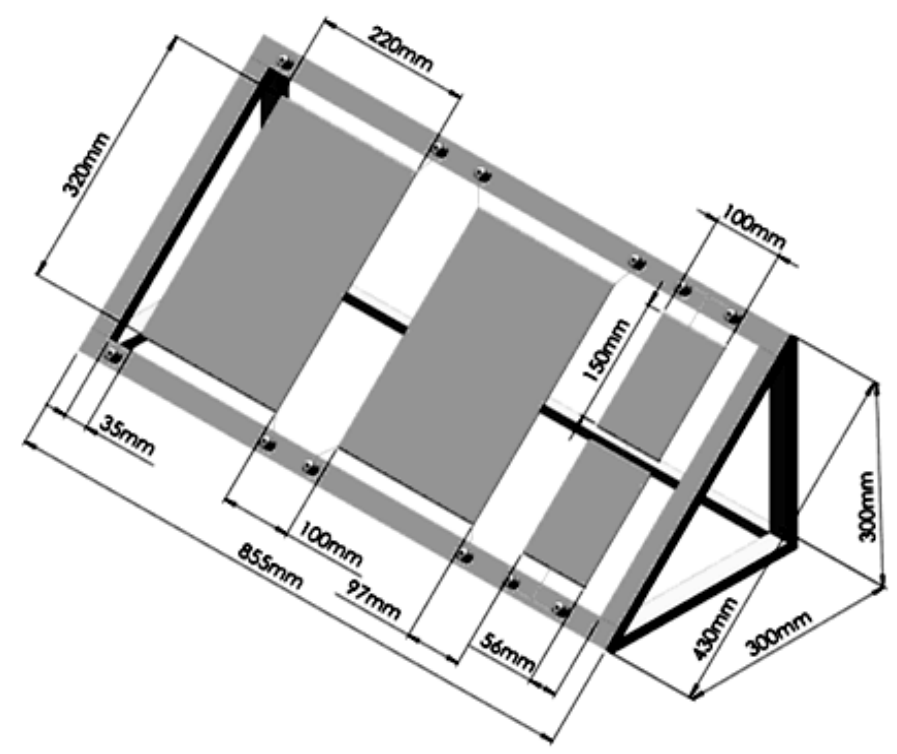

Fig. 4. Wood holder used for the placement of the pollutants device.

\section{Chloride penetration}

Total chloride concentration $\left[\mathrm{Cl}^{-}\right]$in $\%$ weight of concrete was determined at the surface and $1 \mathrm{~cm}$ depth after one year of exposure and at 1 and $2 \mathrm{~cm}$ depth after 2 years of exposure, considering it is the region where chloride penetration occurs due to capillary absorption, that is, depending on the capillarity coefficient of concrete [25]. The influence of the atmospheric environment should be more significant in this part of the concrete cover.

Total chloride concentrations in the surface were determined by scrapping using a metallic spatula up to $1 \mathrm{~mm}$ thickness. For 1 and $2 \mathrm{~cm}$ depth and the surface, three samples of $10 \mathrm{~g}$ of concrete powder were extracted by drilling where the drill diameter was smaller than coarse aggregate size. Thus, three chloride concentration values on the surface as well as 1 and $2 \mathrm{~cm}$ depth were determined in the three samples of reinforced concrete of water/cement ratio $0.4,0.5$ y 0.6 placed in the seven exposure sites in Havana and two samples of reinforced concrete of water/cement ratio 0.5 and 0.6 placed in the two exposure site in Mexico. Therefore, it has 24 values of chloride ion concentration of each reinforced concrete probes and surface at 1 and $2 \mathrm{~cm}$ depth.

\section{Evaluation of corrosion current}

Corrosion current was measured using GECOR-8 instrument. As is known, this equipment is widely used in corrosion potential and corrosion current measurements in the diagnostic work on site. It presents a circular shape sensor in which reference electrodes, in this case Copper/Copper Sulphate and auxiliary electrode are found. Between the sensor surface and the concrete cover surface a wetted cloth was placed in order to ensure good electrolytic contact in the measurement system. This measurement area remained perpendicular to the wind during the first and second year of exposure. Always reinforcing steels rebars to the left to $20 \mathrm{~mm}$ concrete cover and the right to $40 \mathrm{~mm}$ concrete cover as working electrodes were took. The outside area of the reinforcing steel rebars $(40 \mathrm{~mm})$ was made contact with the equipment. This zone had an adhesive tape as a temporal protection against corrosion. Therefore the reinforcing steel rebars length embedded in the reinforced concrete samples was $160 \mathrm{~mm}$. The free area of reinforcing steel rebars for determining the corrosion rate was $65.25 \mathrm{~cm}^{2}$. Epoxy coating was no applied to ensure good electrolytic contact. The corrosion current was determined similar on site, is said, pressing the sensor on the surface of the reinforced concrete sample until to obtain the corrosion current values (Fig. 5). That equipment use polarization resistance technique to obtain corrosion current values. Three corrosion current values for each probes of water/cement ratio $0.4,0.5$ and 0.6 at 2 and $4 \mathrm{~cm}$ concrete cover in the seven exposure sites in Havana were obtained. These variables were only measured in reinforced concrete samples of Havana. 
Therefore, it has 24 values of corrosion current of each reinforced concrete probes at 2 and $4 \mathrm{~cm}$ concrete cover.

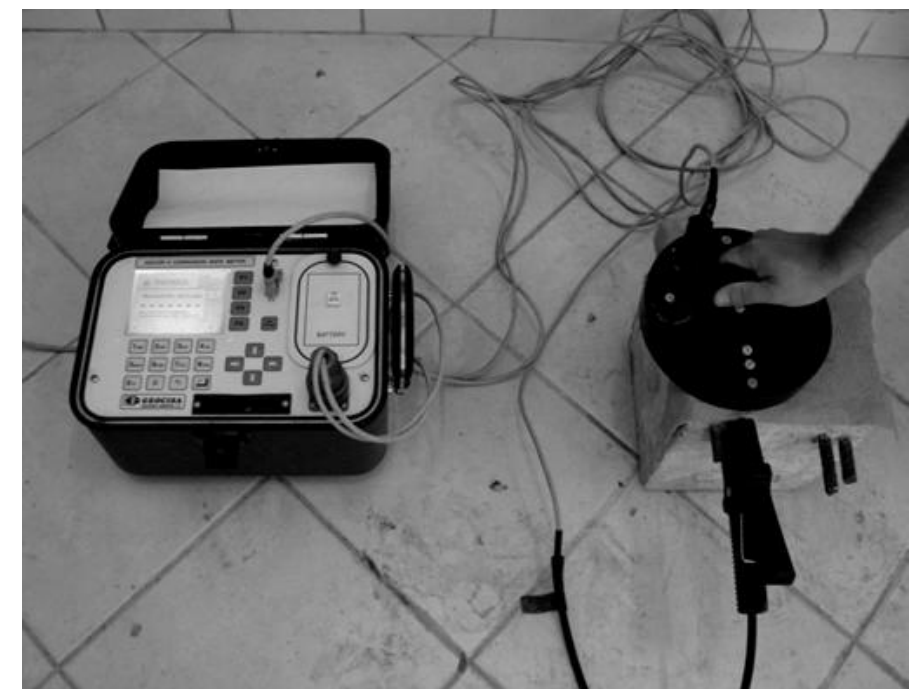

Fig. 5. Measurements system to obtain the reinforcing steel rebars corrosion y reinforced concrete samples.

\section{Statistical treatment of data}

Multilinear and simple regression equations and correlation coefficients were obtained using Statgraphics software version 5.0. It is important to remark that, given the complex nature of atmospheric corrosion phenomenon, it is very common to use statistical treatment of data [26]. Under these conditions, only using statistical treatment of data is possible to elucidate the influence of a complex set of parameters on atmospheric corrosion of materials. It is important to take into account that statistical treatment of data is a very valuable tool, but it should be applied taking into consideration the fundaments of atmospheric corrosion phenomenon.

\section{Results and discussion}

\section{Chlorides deposition rate-First year of exposure in Havana City}

Changes in the CIDR for the closer site to the shoreline in Havana City are presented (Fig. 6). High deposition rate is determined in the winter time (dry season period: November to April). Changes in deposition rate for the other six exposure sites are presented (Fig. 7). The same behavior is observed, the CIDR is higher in the winter time (dry season period). Station No. 4 shows the higher deposition between the six sites, it is located at $1500 \mathrm{~m}$ of the seashore, but at the same time it is placed at about $200 \mathrm{~m}$ of the indoor shore of Havana Bay.

The magnitude of CIDR is extremely high at Station No. 1 ( $20 \mathrm{~m}$ to the shoreline). These conditions should cause a very strong atmospheric corrosion rate at this site. Respecting the other six sites, Station No. 4 presents a C4 atmospheric corrosivity level, Stations No. 2 and 3 show CIDR classification S1 and the other three sites So. 


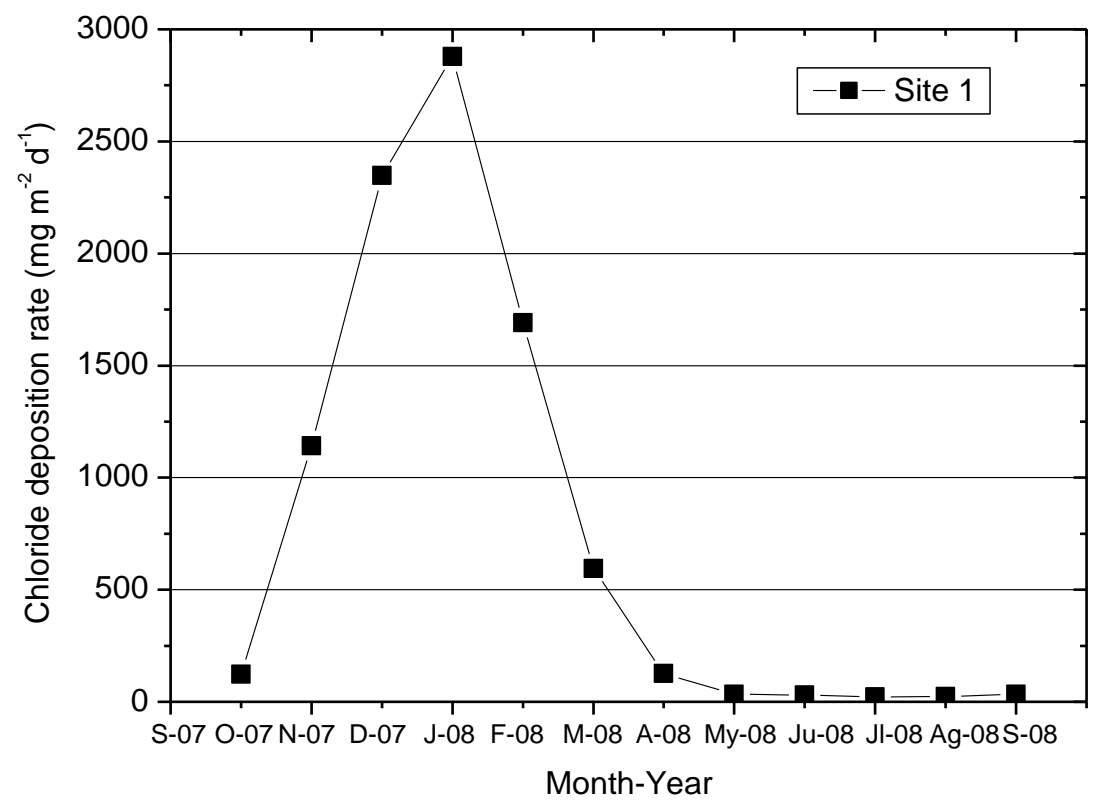

Fig. 6. Monthly chloride deposition rate determined at $20 \mathrm{~m}$ of the shoreline in the Havana City.

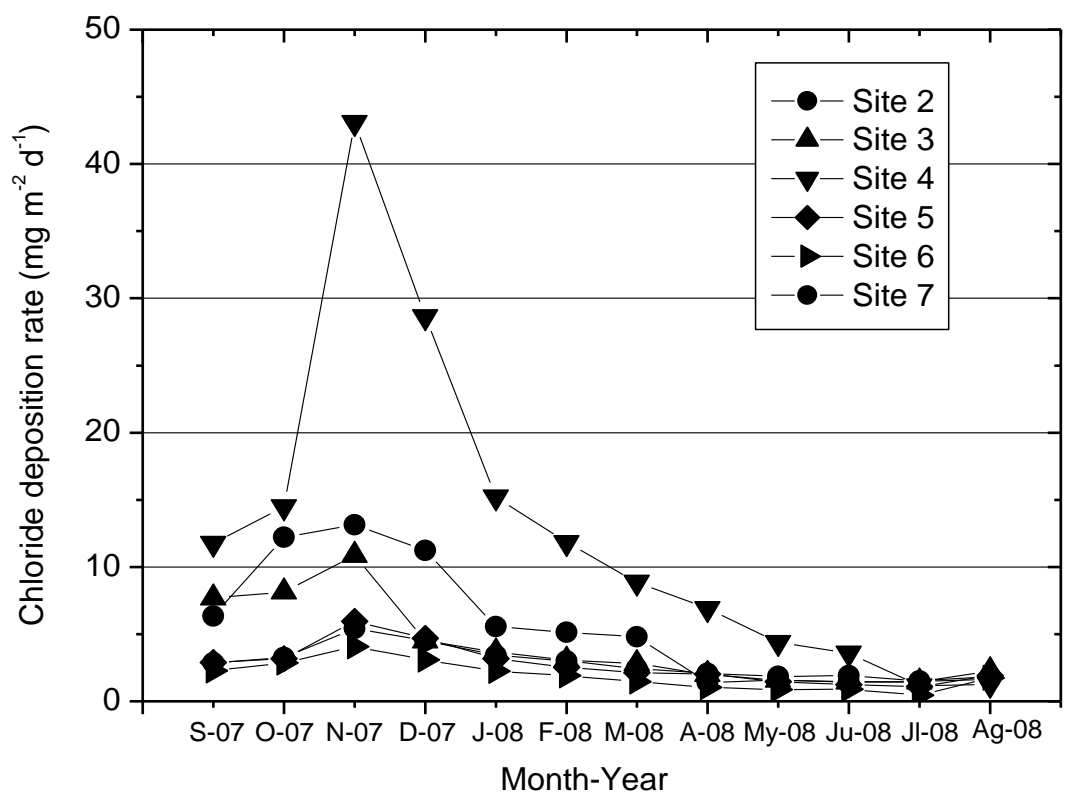

Fig. 7. Monthly chloride deposition rate determined at six exposure sites located at different distances to the shoreline in the Havana City.

Some expressions like $[\mathrm{CIDR}]=\mathrm{ad}^{-\mathrm{b}}$ to represent the change in CIDR with the distance to the shoreline are proposed [20]. CIDR yearly average data determined in seven sites in Havana was processed versus distance to the shoreline and fitted to the following exponential relationship:

$$
[\mathrm{ClDR}]=10170.7[\mathrm{~d}]-1.06 ; \mathrm{n}=7, \mathrm{r}=-0.934, \mathrm{r}^{2}=0.872, \mathrm{P}<0.01
$$

where $\mathrm{d}$ is the distance to the shoreline $(\mathrm{m})$. It means that the same type of expression is obtained in the case of Havana City, that is, a sharp descends in chloride deposition when distance to the seashore increases. Actually, salinity corresponding to Stations No. 2 and 3 should be higher in case of no obstacles for the distribution of sea aerosol. Changes in the coefficients of the above expression probably occur for airborne salinity distribution without obstacles.

\section{Sulphur compounds deposition rate-First year of exposure in Havana City}

The origin of sulphur compounds deposition rate $[\mathrm{SO} \times \mathrm{DR}]$ could be natural or product of the man behavior. It can be seen that the higher sulphur compounds deposition rate corresponds to the exposure 
site located closer to the shoreline (Table 1). The main source of SO $\times$ DR in this case should be the marine aerosol. It is also important to note (Fig. 8) that, similar to CIDR, maximum SO $\times \mathrm{DR}$ is determined in the winter period (Nov-April).

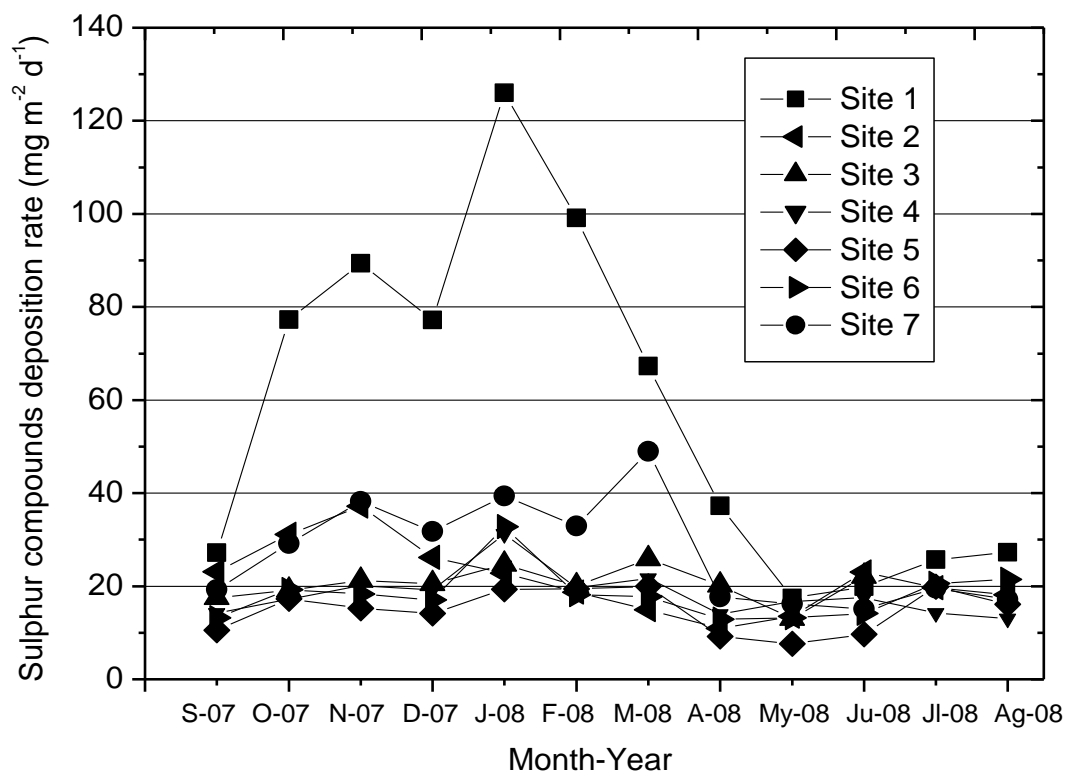

Fig. 8. Monthly sulfur compounds deposition determined at seven exposure sites located at different distances to the shoreline in the City of Havana.

Station No. 4 shows SO $\times$ DR higher than the rest of Havana exposure sites, excepting Station No. 1. Deposition rate is also higher for the winter time; however, it could be possible that the origin of sulphur compounds should not only be due to marine aerosol, but also from industries and urban sources, according to the location of this site. It is important to note that around Havana Bay there is a significant number of industries and other possible sources of contamination.

A general behavior showing a higher SOXDR in winter time is observed for all sites, it means that sulphur compounds of natural origin are a significant part of the total sulphur compound deposition. A similar exponential relation than obtained for chlorides confirms the influence of marine aerosol in SO $\times$ DR:

$$
[\mathrm{SO} \times \mathrm{DR}]=95,06[\mathrm{~d}]^{-0.212} ; \mathrm{n}=7, \mathrm{r}=-0.879, \mathrm{r}^{2}=0.772, \mathrm{P}<0.01
$$

\section{Chloride penetration profiles-First year of exposure in Havana City}

Chloride salts are transported into concrete by a combination of capillary absorption and diffusion, with a preponderance of capillary absorption in the surface layers, where wetting and drying cycles play an important role, and diffusion in inner layers [13].

Chloride concentrations $[\mathrm{Cl}]$ in \% weight of concrete determined (at the concrete surface and at $1 \mathrm{~cm}$ of depth) depending on distance to the shoreline after one year of exposure are presented (Fig. 9) for three water/cement (w/c) ratios in Havana and two w/c ratios in Yucatan Peninsula. For Havana, it can be observed that, in general, chloride concentration is lower on the surface respecting $1 \mathrm{~cm}$ penetration. Samples were evaluated at the end of the wet period (summer), where rain is more intense and frequent. This situation could cause that surface concentration is lower than at $1 \mathrm{~cm}$ penetration. The higher difference between surface concentration and $1 \mathrm{~cm}$ penetration is observed at w/c ratio of 0.6. The effective porosity of Havana samples (Table 3) is almost double for samples with $\mathrm{w} / \mathrm{c}=0.6$, respecting others with lower $\mathrm{w} / \mathrm{c}$ ratios. The higher capillarity absorption coefficient and effective porosity favors the penetration of chloride through the concrete cover.

Respecting Cuban sites, it is interesting to note that a sharp decrease of $\left[\mathrm{Cl}^{-}\right]$takes place from Station No. 1 to Station No. 2, meanwhile Stations No. 3 and No. 4 show higher chloride penetration (Fig. 9). Station No. 2 is screened from a direct arrival of marine aerosol because the site is located in a parking area in the back of a $12^{\text {th }}$ floor building placed in front to the shoreline and screening the direct arrival of airborne salinity. 
At the same time, Station No. 4 is located $1500 \mathrm{~m}$ to the shoreline, but close to the Havana Bay, that is why a higher chloride concentration is determined. Station No. 3 is located at a longer distance to the shoreline, but with fewer obstacles to stop the arrival of airborne salinity, only a group of trees; however, there is a difference between CIDR and $\mathrm{Cl}^{-}$penetration at Station No. 2 because it shows a higher CIDR than Station No. 3 and $\mathrm{Cl}^{-}$is lower.

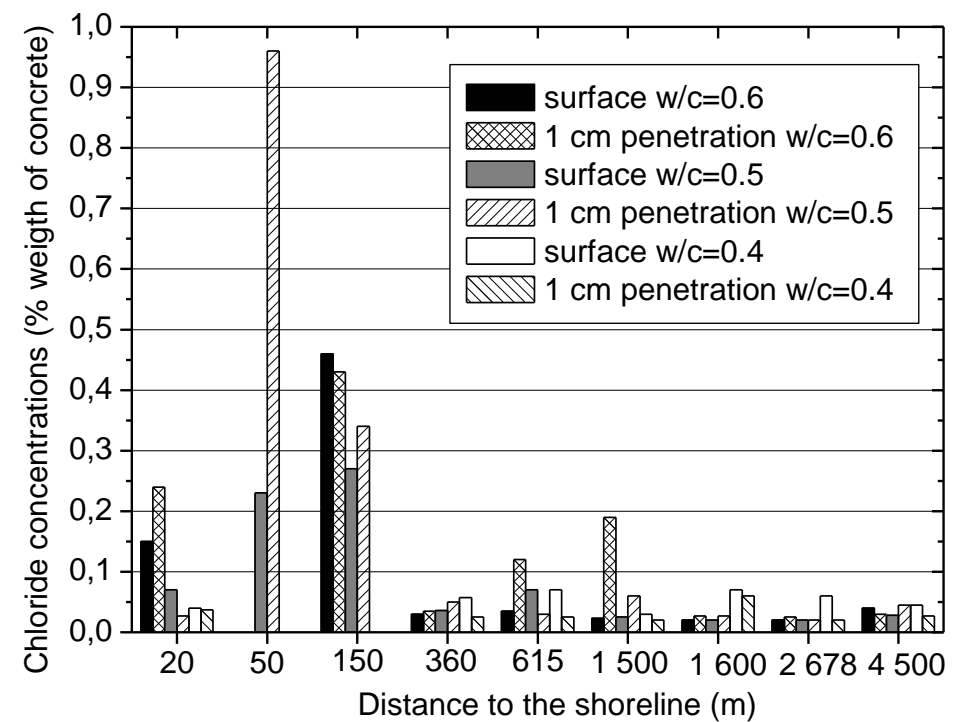

Fig. 9. Chloride concentrations on the surface and at $1 \mathrm{~cm}$ depth into concrete depending on distance to the north shoreline $(\mathrm{m})$ and $\mathrm{w} / \mathrm{c}$ ratio for Havana and Yucatan exposure sites after one year of exposure.

The main difference between these two exposure sites is that Station No. 2 is completely screened from the direct arrival of airborne salinity and that is not the case for Station No. 3, where the front trees can screen part of the direct airborne salinity, but not completely. Station No. 2 reports a lower average relative humidity $(81.6 \%)$ respecting Station No. $3(83.8 \%)$. Perhaps the presence of a high humidity at Station No. 3 and also a higher influence of winds coming from the shoreline could provoke more favorable conditions for chloride penetration, instead to a lower level of chloride deposition. It is also important to note that Station No. 4 (higher average RH than Station No. 2 and a little higher atmospheric chloride deposition) reports a higher chloride penetration. A possible explanation could be that aerosol particles coming to Station No. 2 should have different size than those arriving to Stations No. 3 and 4, because the biggest chloride nuclei should be deposited in the building closer to the shoreline. A difference in sensibility for chloride determination could take place between the surface of the dry plate and the surface of concrete samples. Small chloride particles could be absorbed by dry plate, but those small particles which arrive to concrete surface could be absorbed by dust particles existing in the surface and carried by wind. In case of bigger chloride particles, they could be absorbed by dust presented in the surface of concrete, but remain in the surface because they absorb more water. In the above situation it is observed that for a higher relative humidity a higher chloride concentration is obtained. The existence of a higher humidity could facilitate chloride penetration.

A calculation based on computational fluid dynamic, Cole determines that deposition ratio on a building relative to wet candle is 0.08 for the back of the building [27]. If this calculation could be fitted to Station No. 2, it should mean that chloride deposition, in case of inexistence of the building, should be 12.5 times higher.

A very clear difference in chloride penetration is observed between the three $\mathrm{w} / \mathrm{c}$ ratios tested after one year of exposure in Havana. It means that reinforcing steel corrosion will start before in samples having higher w/c ratio and consequently, higher capillarity absorption coefficient and effective porosity. In the site where an extreme corrosion rate of carbon steel is very probable (Station No. 1), due to a very high CIDR, the higher chloride concentration is reported, particularly for the higher $\mathrm{w} / \mathrm{c}$ ratio.

The other sites located at less than $1 \mathrm{~km}$ of the north shoreline (including Station No. 4 because it is placed near the Havana Bay) could be considered a second level of corrosivity. To the following sites, located at more than $1 \mathrm{~km}$ of the shoreline, perhaps a third level of corrosivity could correspond, including 
also Station No. 2, due to a lower chloride penetration. A longer time of exposure will be necessary to clarify the existence of a third corrosivity level.

It is important to note that samples exposed at Yucatan Peninsula (Station No. 9-50 m to the shoreline and Station No. 8-150 $\mathrm{m}$ to the shoreline) show a significant higher chloride concentration respecting samples exposed in Havana. It is undoubtedly caused by a higher porosity and capillarity of the used concretes, as it is suggested by its significant lower compressive strength. It means that w/c ratio is not the only parameter to take into account concerning chloride concentrations because in the case of Yucatan samples, concrete slump was significantly lower but the absence of use water-reducing admixtures may be an index of higher porosity instead to a similar w/c ratio respecting Havana.

It is important to note that chloride threshold, considered as $0.4 \%$ in weight of cement, has not been reached in any of the samples exposed in Havana after one year of exposure (based on determinations made at $1 \mathrm{~cm}$ penetration). That is not the case for samples exposed two exposure sites selected at Yucatan Peninsula, where all values corresponding to $\mathrm{w} / \mathrm{c}$ ratio 0.6 are over $0.4 \%$ and in the case of $\mathrm{w} / \mathrm{c} 0.5$ the values corresponding to Campeche (Station 9) are higher than for Havana sites, but lower than $0.4 \%$. Chloride penetration for Progresso samples (Station 8) is higher than $0.4 \%$ for w/c 0.5.

A multilinear regression carried out between average chloride concentrations $\mathrm{Cl}^{-}$at $1 \mathrm{~cm}$ depth versus average CIDR determined by dry plate method and water/cement ratio $(\mathrm{w} / \mathrm{c})$ gave the following results:

Penetration of chloride at $1 \mathrm{~cm}$ depth (1 year):

$$
[\mathrm{Cl}]=-0.1+0.0001[\mathrm{ClDR}]+0.27[\mathrm{w} / \mathrm{c}] ; \mathrm{n}=24, \mathrm{r}^{2}=55.07, \mathrm{P}<0.01
$$

where $\mathrm{w} / \mathrm{c}$ is the water/cement ratio. It shows that $\mathrm{w} / \mathrm{c}$ ratio and atmospheric CIDR are two very important variables in determining chloride penetration at $1 \mathrm{~cm}$ depth, but only less than $60 \%$ changes in chloride penetration at $1 \mathrm{~cm}$ depth are explained by the obtained relation. A similar dependence is obtained if instead of $\mathrm{w} / \mathrm{c}$ ratio, capillarity absorption coefficient is included:

Penetration of chloride at $1 \mathrm{~cm}$ depth (1 year):

$$
[\mathrm{Cl}]=-0.004+0.0001[\mathrm{ClDR}]+5.16[\mathrm{~K}] ; \mathrm{n}=24, \mathrm{r}^{2}=56.96, \mathrm{P}<0.01
$$

where $\mathrm{K}$ is the capillarity absorption coefficient $\left(\mathrm{kg} / \mathrm{m}^{2} \mathrm{~s}^{1 / 2}\right)$.

In case of the effective porosity the results are the followings:

Penetration of chloride at $1 \mathrm{~cm}$ depth (1 year):

$$
[\mathrm{Cl}]=-0.03+0.0001[\mathrm{ClDR}]+0.005[\varepsilon] ; \mathrm{n}=24, \mathrm{r}^{2}=55.75, \mathrm{P}<0.01
$$

where $\varepsilon$ is the effective porosity (\%). The above regression equations show that almost an equivalent influence of water/cement ratio, absorption coefficient and effective porosity is obtained on chloride penetration at $1 \mathrm{~cm}$ depth after one year of exposure. It is clarified that the eight values of capillarity absorption coefficient and porosity for the water / cement ratios three were not determined for one year of exposure of the sample, but also the values were taken after 28 days of curing. Theses parameters not vary much with the time [11].

\section{Chloride profile after two years of exposure in Havana}

After two years of exposure, chloride concentrations at 1 and $2 \mathrm{~cm}$ depth are significantly higher at Station No. 1 (Fig. 10). In case of $\mathrm{w} / \mathrm{c}=0.6$ and $\mathrm{w} / \mathrm{c}=0.5$, chloride percent is higher at $1 \mathrm{~cm}$ depth respecting $2 \mathrm{~cm}$. Chloride concentration is significantly different in Station No. 1 respecting all other sites located more inland. Concerning the reinforcing steel rebars corrosion; it should be significantly higher in Station No. 1 respecting the other sites. The results of statistical regression between $\mathrm{Cl}^{-}$and $\mathrm{CIDR}$ (first year average) in concrete at 1 and $2 \mathrm{~cm}$ of depth after two years of exposure, are presented (Table 4). It can be noted that, excepting for $\mathrm{w} / \mathrm{c}=0.5$ after one year of exposure, a good statistical fitness is obtained.

For all $\mathrm{w} / \mathrm{c}$ ratios and $1 \mathrm{~cm}$ depth-2 years of exposure:

$$
[\mathrm{Cl}]=-0.1+0.0004[\mathrm{ClDR}]+0.28[\mathrm{w} / \mathrm{c}] ; \mathrm{n}=24, \mathrm{r}^{2}=0.76, \mathrm{P}<0.01
$$

For all $\mathrm{w} / \mathrm{c}$ ratios and $2 \mathrm{~cm}$ depth-2 years of exposure:

$$
[\mathrm{Cl}]=-0.03+0.00023[\mathrm{CIDR}]+0.11[\mathrm{w} / \mathrm{c}] ; \mathrm{n}=24, \mathrm{r}^{2}=0.87, \mathrm{P}<0.01
$$

Significant relations are obtained between the average CIDR corresponding to the first year of exposure and $[\mathrm{Cl}]$ at 1 and $2 \mathrm{~cm}$ depth after two years taking into account $\mathrm{w} / \mathrm{c}$ ratio. CIDR for the second year of exposure was not measured, but it is probable that the ratio of chloride deposition between sites in the second year should be similar to the first one. Changes are better explained for two years of exposure. These results show that the influence of CIDR rules chloride penetration in samples exposed in Havana sites. 


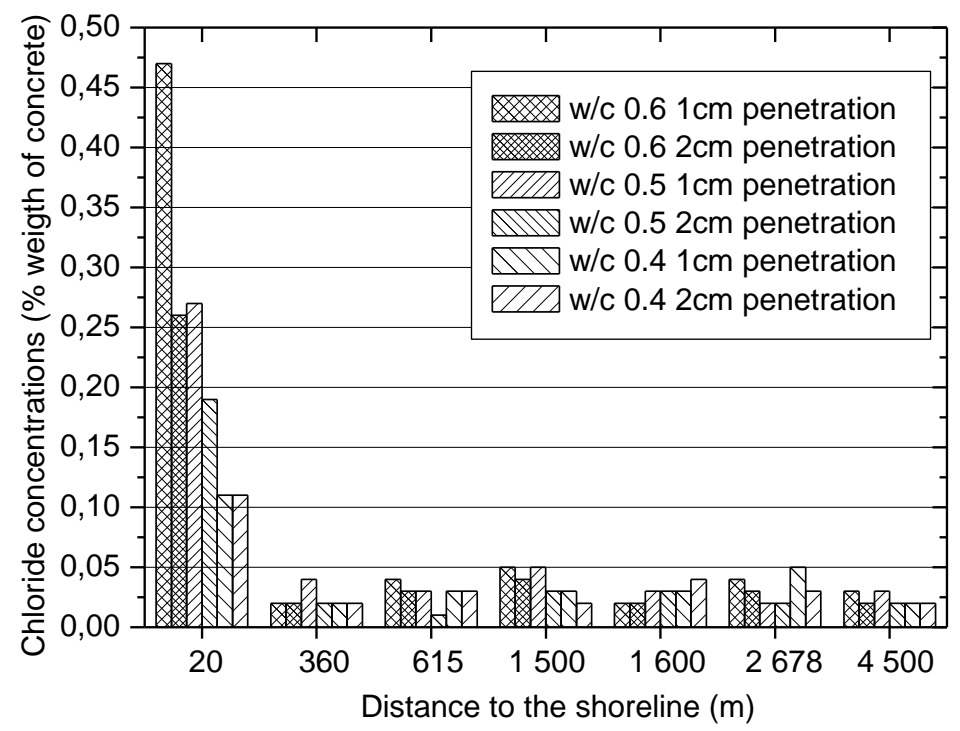

Fig. 10. Chloride penetration after one year of exposure on the surface and at $1 \mathrm{~cm}$ depth into concrete depending on distance to the north shoreline and $\mathrm{w} / \mathrm{c}$ ratio.

Table 4. Statistical regressions between chloride concentration in concrete at 1 and $2 \mathrm{~cm}$ of depth after two years of exposure sites in Havana at three different w/c ratios and chloride deposition rate (first year average).

\begin{tabular}{|c|c|c|c|c|c|}
\hline \multicolumn{6}{|c|}{ Regression Equation: $\mathrm{Cl}^{-}(\%)=\mathrm{a}+\mathrm{b}[\mathrm{ClDR}]\left(\mathrm{mg} \mathrm{m}^{-2} \mathrm{~d}^{-1}\right)$} \\
\hline $\begin{array}{l}\text { Chloride } \\
\text { Penetration } \\
\text { Depth }(\mathrm{cm})\end{array}$ & $\mathbf{w} / \mathbf{c}$ & $\mathbf{r}$ & $\mathbf{r}^{2}(\%)$ & $\mathbf{P}$ & Regression Equation \\
\hline 1 & 0.6 & 0.90 & 81.0 & $(\mathrm{p}$-valor $)<0.01$ & $\mathrm{Cl}^{-}=0.05+0.0003[\mathrm{ClDR}]$ \\
\hline 1 & 0.5 & 0.73 & 53.0 & $(\mathrm{p}$-valor $)<0.10$ & $\mathrm{Cl}^{-}=0.03+0.0005[\mathrm{ClDR}]$ \\
\hline 1 & 0.4 & 0.99 & 99.0 & $(\mathrm{p}$-valor $)<0.01$ & $\mathrm{Cl}^{-}=0.02+0.0003[\mathrm{ClDR}]$ \\
\hline 2 & 0.6 & 0.99 & 99.0 & $(\mathrm{p}$-valor $)<0.01$ & $\mathrm{Cl}^{-}=0.02+0.0003[\mathrm{ClDR}]$ \\
\hline 2 & 0.5 & 0.99 & 99.0 & $(\mathrm{p}$-valor $)<0.01$ & $\mathrm{Cl}^{-}=0.02+0.0002[\mathrm{ClDR}]$ \\
\hline 2 & 0.4 & 0.97 & 94.0 & $(\mathrm{p}$-valor $)<0.01$ & $\mathrm{Cl}^{-}=0.02+0.0001[\mathrm{ClDR}]$ \\
\hline
\end{tabular}

\section{Corrosion current (CC)}

Regression equations obtained between corrosion current and chloride penetration after two years of exposure for different $\mathrm{w} / \mathrm{c}$ ratios and the concrete cover thicknesses are presented (Table 5).

It is observed that a significant regression is obtained for $\mathrm{w} / \mathrm{c}$ ratio 0.6 and $\mathrm{w} / \mathrm{c}$ ratio 0.5 . It could be explained because these two $\mathrm{w} / \mathrm{c}$ ratios are more porous than $\mathrm{w} / \mathrm{c}$ ratio 0.4 and chloride concentrations are higher. In the case of the last $\mathrm{w} / \mathrm{c}$ ratio, reinforcing steel rebars corrosion should not be significant after two years of exposure. Only one statistical significant regression equation is obtained (4 cm cover). These regressions equations show a direct relation between corrosion current measured and chloride penetration in concrete.

Statistical results obtained between corrosion current determined after one and two years of exposure and average CIDR determined during the first year of exposure in exposure sites in Havana for different $\mathrm{w} / \mathrm{c}$ ratios are presented (Table 6 ). Similar to chloride penetration, no significant regressions are obtained for $\mathrm{w} / \mathrm{c}$ ratio 0.4 ; however, a good fitness is obtained for $\mathrm{w} / \mathrm{c}$ ratio 0.6 including the first year of exposure. An acceptable fitness is also obtained for w/c ratio 0.5 after two years of exposure. It means that CIDR is a very important parameter in determining the corrosion current and consequently, the corrosivity of the atmosphere respecting to steel reinforced concrete.

Multilinear regression analysis between corrosion current, CIDR (first year average) and w/c ratio for one and two years were carried out. The results were the following:

One year of exposure $(2 \mathrm{~cm}$ cover $)$ :

$$
[\mathrm{Ic}]=\text { Corrosion current }\left(\mu \mathrm{A} / \mathrm{cm}^{2}\right)
$$

$$
[\mathrm{Ic}]=-0.06+0.42[\mathrm{CIDR}]+0.18[\mathrm{w} / \mathrm{c}] ; \mathrm{n}=24, \mathrm{r}^{2}=56.0 \%, \mathrm{P}<0.01
$$


Two years of exposure $(2 \mathrm{~cm}$ cover):

Two years of exposure $(4 \mathrm{~cm}$ cover):

$$
[\mathrm{Ic}]=-0.07+0.00009[\mathrm{ClDR}]+0.22 \mathrm{w} / \mathrm{c} ; \mathrm{n}=24, \mathrm{r}^{2}=69.0 \%, \mathrm{P}<0.01
$$

$$
[\mathrm{Ic}]=-0.05+0.00005[\mathrm{ClDR}]+0.19[\mathrm{w} / \mathrm{c}] ; \mathrm{n}=24, \mathrm{r}^{2}=67.0 \%, \mathrm{P}<0.01
$$

A significant statistical probability about the influence of CIDR and $\mathrm{w} / \mathrm{c}$ ratio in the corrosion current determined is obtained; although the explanation of changes $\left(\mathrm{r}^{2}\right)$ is lower than $70 \%$.

Table 5. Statistical regressions between corrosion current and chloride concentration at 2 and $4 \mathrm{~cm}$ of

\begin{tabular}{|c|c|c|c|c|c|c|}
\hline \multicolumn{7}{|c|}{$\begin{array}{c}\text { Regression Equation: }[\mathrm{Ic}]=\mathrm{a}+\mathrm{b}[\mathrm{Cl}-] \\
\mathrm{n}=24\end{array}$} \\
\hline $\begin{array}{l}\text { Cover } \\
(\mathrm{cm})\end{array}$ & $\begin{array}{c}\text { Chloride } \\
\text { Penetration } \\
\text { Depth }(\mathrm{cm})\end{array}$ & $\mathrm{w} / \mathrm{c}$ & $\mathbf{r}$ & $\mathbf{r}^{2}(\%)$ & $\mathbf{P}$ & Regression Equation \\
\hline 2 & 1 & 0.6 & 0.92 & 85.0 & $(\mathrm{p}$-valor $)<0.01$ & {$[\mathrm{Ic}]=0.04+0.2\left[\mathrm{Cl}^{-}\right]$} \\
\hline 2 & 1 & 0.5 & 0.93 & 86.0 & (p-valor $)<0.01$ & {$[\mathrm{Ic}]=0.02+0.42[\mathrm{Cl}-]$} \\
\hline 2 & 1 & 0.4 & -0.13 & 2.0 & Not significant & {$[\mathrm{Ic}]=0.02-0.03\left[\mathrm{Cl}^{-}\right]$} \\
\hline 2 & 2 & 0.6 & 0.93 & 86.0 & $(\mathrm{p}$-valor $)<0.01$ & {$[\mathrm{Ic}]=0.04+0.40[\mathrm{Cl}]$} \\
\hline 2 & 2 & 0.5 & 0.91 & 87.0 & (p-valor $)<0.01$ & {$[\mathrm{Ic}]=0.02+0.56\left[\mathrm{Cl}^{-}\right]$} \\
\hline 2 & 2 & 0.4 & 0.006 & 0.04 & Not significant & {$[\mathrm{Ic}]=0.02+2 \mathrm{E}-06[\mathrm{Cl}-]$} \\
\hline 4 & 2 & 0.6 & 0.86 & 74.0 & (p-valor $)<0.05$ & {$[\mathrm{Ic}]=0.05+0.32\left[\mathrm{Cl}^{-}\right]$} \\
\hline 4 & 2 & 0.5 & 0.83 & 69.0 & (p-valor $)<0.05$ & {$[\mathrm{Ic}]=0.03+0.21[\mathrm{Cl}]$} \\
\hline 4 & 2 & 0.4 & 0.79 & 62.0 & (p-valor $)<0.05$ & {$[\mathrm{Ic}]=0.02+0.19\left[\mathrm{Cl}^{-}\right]$} \\
\hline
\end{tabular}
depth to different w/c ratios after two years of exposure in Havana City sites.

Table 6. Statistical regressions between corrosion current chloride deposition rate in the first year of exposure at 2 and $4 \mathrm{~cm}$ of cover for different $\mathrm{w} / \mathrm{c}$ ratios after two years of exposure in Havana City sites.

\begin{tabular}{lcccccc}
\hline \multicolumn{7}{c}{ Regression equation: [Ic] = a + b[ClDR] } \\
$\mathbf{n}=\mathbf{2 4}$
\end{tabular}

In general, corrosion current changes according to $\mathrm{Cl}^{-}$and $\mathrm{CIDR}$. It indicates that, for exposure sites coastal in Havana City, atmospheric corrosivity respecting reinforcing steel rebars after two years of exposure depends on CIDR and $\mathrm{w} / \mathrm{c}$ ratio.

Normally, the influence of SOXDR in atmospheric corrosion of reinforcing steel rebars in coastal sites is not considered. The results of statistical regressions between corrosion current with CIDR and SOXDR for different $\mathrm{w} / \mathrm{c}$ ratios are presented (Table 7). The inclusion of SO $\times \mathrm{DR}$ in statistical regression increases statistical fitness for w/c ratio 0.6. Significant regression equations are obtained when $\mathrm{SO} \times \mathrm{DR}$ is included for other w/c ratios. Only for w/c ratio 0.5 , one year of exposure and concrete cover $2 \mathrm{~cm}$ a significant regression equation is not obtained. It means that $\mathrm{SO} \times \mathrm{DR}$ could also influence on corrosion of steel reinforced concrete. Coefficient " $\mathrm{c}$ " represents the influence of SOXDR in corrosion current. As can be observed, excepting for $\mathrm{w} / \mathrm{c}=0.6$ in the first year, it has a positive sign. 
Table 7. Statistical regressions between corrosion current chloride deposition rate and sulphur compounds deposition rate average to first year of exposure at 2 and $4 \mathrm{~cm}$ cover for 1 and 2 of exposure in Havana City sites.

\begin{tabular}{lccccc}
\hline \multicolumn{7}{c}{ Regression equation: [Ic] $\mathbf{= a}+\mathbf{b}[\mathrm{ClDR}]+\mathbf{c}[\mathrm{SO} \times-\mathrm{D}]$} \\
$\mathbf{n = 2 4}$
\end{tabular}

It means that the influence of $\mathrm{SO} \times \mathrm{DR}$ increase corrosion current. A negative sign for coefficient " $\mathrm{b}$ " which represents the influence of CIDR on corrosion current is observed in regressions obtained for $\mathrm{w} / \mathrm{c}$ ratio 0.4. It could be due to the low porosity of these reinforced concrete samples. Perhaps the influence of $\mathrm{CIDR}$ is not significant at the present time of exposure for this $\mathrm{w} / \mathrm{c}$ ratio.

Reinforced concrete has been extensively used in all environments. Apart from the effect of sulphates ions on attacking hardened concrete, which is relatively voluminously researched in the literature, there is little data available on the role of sulphates ions in the corrosion of steel reinforced concrete because of the lack of understanding about the role these ions. However, the exposure of many reinforced concrete structures to sulphate-bearing soils and groundwater has brought attention to the role of sulphate ions in the corrosion of steel reinforced concrete, either when the sulphate ions are present alone or when they exist concurrently with chlorides [28].

The sulphate ions production in the atmosphere takes place either by photo-oxidation of dimetil sulphide or oxidations $\mathrm{SO}_{2}$ in the atmosphere. The sulphate ions are formed from the photo-oxidation of dimetil sulphide that is transferred from sea to the atmosphere in presence of the solar light. The process is named gas particle conversion wish one occurs in the wind sea interface [29].

When marine aerosol is transported to island by wind, in urban zone its gases incorporate of anthropogenic source principality the $\mathrm{SO}_{2}$, in this case occurs the gas particle conversion too, where the $\mathrm{SO}_{2}$ is transformed to sulphate ions from the oxidations in presence of the ozone in the atmosphere [30]. These sulphate ions penetrate into reinforced concrete structure reacting with chemicals originating from the cement hydration process $\left(\mathrm{Ca}(\mathrm{OH})_{2}\right)$. The most frequent attack by sulphate ions is the reaction of gypsum (calcium sulfate, $\mathrm{CSH}_{2}$ ) with hydrated compounds cement to form secondary ettringite $\left(\mathrm{C}_{6} \mathrm{AS}_{3} \mathrm{H}_{31}\right)$ which produces the expansion and cracked of cured concrete [30].

These results show the influence of $S O \times D R$ could be considered to study atmospheric corrosion of steel reinforced concrete; however, a deeper research should be made in this direction. It should be considered that $\mathrm{SO} \times \mathrm{DR}$ is mainly from natural origin, coming with chloride aerosol [13].

\section{Conclusions}

In the present paper were obtained valuable information for maintenance, construction, designing and protection of reinforced concrete structures in the coastal regions in Havana City and Yucatan Peninsula according to:

- Two significantly different corrosivity levels have been observed after two years of exposure in Havana City Cuba sites as function of atmospheric chloride deposition.

- Changes in corrosion current are in accordance with changes in chloride penetration in concrete and atmospheric chloride deposition. 
- The influence of atmospheric sulphur compounds deposition should be considered to study atmospheric corrosion of reinforced steel.

- Chloride concentration diminishes in areas where airborne salinity does not reach directly the concrete surface due to the presence of obstacles like buildings, trees and so on.

- Changes in the slump of the concretes caused by the use of water reducing additives and differences in the aggregates properties, influence on chloride penetration at the same $\mathrm{w} / \mathrm{c}$ ratio of the concretes.

\section{Acknowledgements}

The investigation carried out in Havana has been supported by the Research Program, Branch 02 "Development and Introduction of Advanced Technologies in Concretes and Mortars Production", of Cuban Construction Ministry.

\section{References}

[1] Corrosion of Metals and Alloys—Corrosivity of Atmospheres—Classification, ISO 9223: 1992.

[2] F. Corvo, T. Perez, L. R. Dzib, Y. Martin, A. Castaneda, E. Gonzalez, and J. Perez, "Outdoor-indoor corrosion of metals in tropical coastal atmospheres," Corros. Sci., vol. 50, pp. 220-230, 2008.

[3] F. Corvo, N. Betancourt, and A. Mendoza, "The influence of airborne salinity on the atmospheric corrosion of steel," Corros. Sci., vol. 37, pp. 1889-1901, 1995.

[4] M. Morcillo, E. Almeida, B. Rosales, J. Uruchurtu, and M. Marrocos, "Corrosión y protección de metales en las atmósferas de Iberoamérica. Parte I-Mapas de Iberoamérica de corrosividad atmosférica," programa CYTED 1998, Editorial Gráficas Salué, S.A., Spain, 1998.

[5] L. Mariaca-Rodriguez, E. Almeida, A. de Bósquez, A. Cabezas, J. Fernando-Alvarez, G. Joseph, M. Marrocos, M. Morcillo, J. Peña, M. R. Prato, S. Rivero, B. Rosales, G. Salas, J. Uruchurtu-Chavarín, and A. Valencia, "Marine atmospheric corrosion of reference metals in tropical climates of LatinAmerica," in Marine Corrosion in Tropical Environments, S. W. Dean, G. Hernández-Duque, and J. B. Bushman, Eds. West Conshohocken, PA, USA: ASTM STP 1399 Publication, 2000.

[6] F. Corvo, J. Minotas, J. Delgado, and C. Arroyave, "Changes in atmospheric corrosion rate caused by chloride ions depending on rain regime," Corros. Sci., vol. 47, pp. 883-892, 2005.

[7] M. Natesan, G. Venkatachari, and N. Palaniswamy, "Kinetics of atmospheric corrosion of mild steel, zinc, galvanized iron and aluminium at 10 exposure stations in India," Corros. Sci., vol. 48, pp. 35843608, 2006.

[8] T. T. N. Lan, N. T. P. Thoa, R. Nishimura, Y. Tsujino, M. Yokoi, and Y. Maeda, "Atmospheric corrosion of carbon steel under field exposure in the southern part of Vietnam," Corros. Sci., vol. 48, pp. 179-192, 2006.

[9] A. A. Mikhailov, P. V. Strekalov, and Y. M. Panchenko, "Atmospheric corrosion in tropical and subtropical climate zones: 3. Modeling corrosion and dose-response function for structural metals," Prot. Met., vol. 43, pp. 619-627, 2007.

[10] J. Tidblad, V. Kucera, F. Samie, S. N. Das, C. Bhamornsut, L. C. Peng, K. L. So, Z. Dawei, L. T. H. Lien, H. Schollenberger, C. V. Lungu, and D. Simbi, "Exposure programme on atmospheric corrosion effects of acidifying pollutants in tropical and subtropical climates," Water Air Soil Pollut.: Focus, vol. 7, pp. 241-247, 2007.

[11] J. J. Beaudoin and J. Marchand, "Pore structure," in Handbook of Analytical Techniques in Concrete Science and Technology: Principles, Techniques and Applications, V. S. Ramachandran and J. J. Beaudoin Eds. New Jersey, USA: Noyes publications/William Andrew, 2001.

[12] Paint and Varnishes-Corrosion Protection of Steel Structures by Protective Paint Systems, ISO 12944: 1998.

[13] U. Angst, B. Elsener, C. K. Larsen, and $\varnothing$. Vennesland, "Critical chloride content in reinforced concrete- A review," Cement and Concrete Research, vol. 39, pp. 1122-1138, 2009.

[14] E. Bastidas-Arteaga, A. Chateauneuf, M. Sanchez-Silva, Ph. Bressolette, and F. Schoefs, "Influence of weather and global warming in chloride ingress into concrete: A stochastic approach," Struct. Saf., vol. 32, pp. 238-249, 2010.

[15] P. Castro, "The atmospheric corrosion performance of reinforced concrete in the Peninsula of Yucatán, México. A review," Corros. Rev., pp. 333-382, 1999. 
[16] O. Trocónis de Rincón, C. Andrade, M. Barboza, F. Irassar, J. C. Montenegro, M. G. de Lima, P. Helene, R. Vera, A. M. Carvajal, R. M. de Gutiérrez, S. Del Vasto, E. Saborio, A. Torres-Acosta, J. Pérez-Quiroz, M. Martínez-Madrid, P. Castro-Borges, E. I. Moreno, M. Salta, A. P. de Melo, I. Martínez, M. Castellote, G. Rodríguez, M. Derrégibus, M. Sánchez, E. A. de Partidas, and R. Fernández, "Durability of concrete structures: DURACON, an iberoamerican project. Preliminary results," Building and Environment, vol. 41, no. 7 pp. 952-962, 2006.

[17] O. Trocónis de Rincón, M. Sánchez, V. Millano, R. Fernández, E. A. de Partidas, C. Andrade, , I. Martínez, M. Castellote, M. Barboza, F. Irassar, J. C. Montenegro, R. Vera, A. M. Carvajal, R. M. de Gutiérrez, J. Maldonado, C. Guerrero, E. Saborio-Leiva, A. C. Villalobos, G. Tres-Calvo, A. TorresAcosta, J. Pérez-Quiroz, M. Martínez-Madrid, F. Almeraya-Calderón, P. Castro-Borges, E. I. Moreno, T. Pérez-López, M. Salta, A. P. de Melo, G. Rodríguez, M. Pedrón, and M. Derrégibus, "Effect of the marine environment on reinforced concrete durability in Iberoamerican countries: DURACON project/CYTED," Corros. Sci., vol. 49, pp. 2832-2843, 2007.

[18] G. R. Meira, C. Andrade, I. J. Padaratz, C. Alonso, and J. C. Borba Jr., "Chloride penetration into concrete structures in the marine atmosphere zone-Relationship between deposition of chlorides on the wet candle and chlorides accumulated into concrete," Cem. Concr. Compos., vol. 29, pp. 667-676, 2007.

[19] K. M. Anwar Hossain, S. M. Easa, and M. Lachemi, "Evaluation of the effect of marine salts on urban built infrastructure," Build. Environ., vol. 44, pp. 713-722, 2009.

[20] G. R. Meira, M. C. Andrade, I. J. Padaratz, M. C. Alonso, and J. C. Borba Jr., "Measurements and modelling of marine salt transportation and deposition in a tropical region in Brazil," Atmos. Environ., vol. 40, pp. 5596-5607, 2006.

[21] A. Saputra, E. Limsuwan, and T. Ueda, "Characteristics of material and fabrication for concrete structures in Indonesia," Engineering Journal, vol. 14, no. 4., pp. 11-22, 2010.

[22] Hormigón endurecido. Determinación de la absorción de agua por capilaridad, 1. Edición. Cuban Standard 345: Diciembre 2005.

[23] Chloride Content Determination in the Atmosphere, Cuban Standard 12-01-09: 1988.

[24] Sulphur Compounds Determination in the Atmosphere, Cuban Standard 12-01-08: 1988.

[25] Standard Test Methods for Chemical Analysis of Hydraulic Cement, Annual Book ASTM Standards, 04.01, West Conshohocken, USA, 2000.

[26] Standard Guide for Applying Statistics to Analysis of Corrosion Date, ASTM G-16, Annual Book of ASTM Standards, Philadelphia, USA, 2000.

[27] I. S. Cole and D. A. Paterson, "Holistic model for atmospheric corrosion. Part 5 - Factors controlling deposition of salt aerosol on candles, plates and buildings," J. Corros. Sci. Eng., vol. 39, 2004.

[28] O. Saeed, "Sulfate attack and reinforcing corrosion in plain and blended cements exposed to sulfate environments," Building and Environment, vol. 33, pp. 53-61, 1998.

[29] J. Piazzola and S. Despiau, "Contribution of marine aerosols in the particle size distributions observed in Mediterranean coastal zone," Atmospheric Environment, vol. 18, pp. 2991-3009, 1997.

[30] C. D. O'Dowd, M. H. Smith, I. A. Consterdine, and J. A. Lowe, "Marine aerosol, sea-salt, and the marine sulphur cycle: A short review," Atmospheric Environment, vol. 31, pp. 73-80, 1997. 